\title{
Synthesis of process related compounds of Nafcillin sodium
}

\author{
Korrapati. V. V. Prasada Rao, ${ }^{a}$ Ramesh Dandala, ${ }^{a^{*}}$ Vijay. K. Handa ${ }^{a}$, \\ Inti. V. Subramnyeswara Rao, ${ }^{a}$ Ananta Rani, ${ }^{a}$ and Andra Naidu . \\ ${ }^{a}$ APL Research Center, A Division of Aurobindo Pharma Ltd, Hyderabad-500072, Andhra \\ Pradesh, India \\ bawaharlal Nehru Technological University, Kukatpally, Hyderabad-500072, \\ Andhra Pradesh, India \\ E-mail: rdandala@aurobindo.com
}

\begin{abstract}
Synthesis of process related impurities of Nafcillin Sodium 3, generated during the preparation of Nafcillin Sodium Bulk drug is described. The compounds were identified as $(2 R S, 4 S)$-2[[[(1R)-1-carboxy-1- (2-ethoxy-1-naphthyl) carbonyl] amino] methyl]-5,5-dimethyl-1,3-thiazolidine-4-carboxylic acid 4, (2RS, 4S)-2-[[[(2-ethoxy-1-naphthyl) carbonyl] amino] methyl]-5,5dimethyl-1,3-thiazolidine-4-carboxylic acid 5, (2S, 5R, 6R)-6-[[(2-ethoxy-1-naphthyl) carbonyl]amino]-3,3-dimethyl-7-azabicyclo [3.2.0] heptane-2-carboxylic acid-4-oxide 6, (2S, 5R, 6R)-6[[2-methoxy-1-naphthyl) carbonyl] amino]-3,3-dimethyl-7-oxo-4-thia-1-azabicyclo[3.2.0] heptane-2-carboxylic acid 8 and (2RS, 4S)-2-[[[(1R)-(2-methoxycarbonyl)-1-(2-ethoxy-1-naphthyl)carbonyl] amino] methyl] -5,5-dimethyl-1, 3-thiazolidine-4-carboxylic acid 9.
\end{abstract}

Keywords: Nafcillin sodium, pharmaceuticals, impurities, synthesis, spectroscopy

\section{Introduction}

Nafcillin Sodium 3 is chemically designated as mono sodium (2S, 5R, 6R)-6-[[2-ethoxy-1naphthyl) carbonyl] amino]-3,3-dimethyl-7-oxo-4-thia-1-azabicyclo [3.2.0] heptane-2-carboxylate. Nafcillin Sodium is a semi synthetic penicillin antibiotic substance derived from 6-aminopenicillanic acid $^{1-4}$. Antibacterial agents of penicillin family have proved highly effective in the therapy of infections due to gram- positive bacteria, but most such agents suffer from the serious drawback of being ineffective against numerous resistant strains of pathogenic bacteria, particularly various staphylococci. Nafcillin Sodium is highly resistant to inactivation by staphylococci penicillanase and is active against penicillinase-producing and non-penicillinaseproducing strains of Staphylococcus aurous ${ }^{5}$ and it is administered orally and by intramuscular and intravenous injection. The impurity profile of Nafcillin Sodium was not reported previously 
to the best of our knowledge. However, the degradation of nafcillin sodium in aqueous solution was discussed in the literature ${ }^{6}$. The preparation of all the contaminants has been necessary to prepare references for the method validation of bulk drugs and formulations. In order to have a high bench marking in quality and to meet various guidelines such as International Conference on Harmonization $(\mathrm{ICH})$ and regulatory requirements it is imperative to identify impurities present in greater than $0.1 \%$ level. $^{7}$

\section{Results and Discussion}

A convenient method was developed for the preparation of a penicillin antibacterial agent, Nafcillin Sodium with high purity. The procedure involves the acylation of 6-aminopenicillanic acid (6-APA) 2 with 2-ethoxy-1-naphthoyl chloride 1 in the presence of triethylamine. After completion of the reaction Nafcillin acid was extracted into methylene chloride by adjusting the $\mathrm{pH}$ to acidic. After acid base treatment Nafcillin acid was extracted into ethyl acetate. Thereafter, the corresponding sodium salt was isolated from the ethyl acetate solution by the addition of sodium 2-ethylhexanoate. (Scheme 1). During the analysis of various batches of Nafcillin Sodium bulk drug, five unknown impurities were detected in a level of $0.05-0.2 \%$. These impurities were synthesized chemically and fully characterized. The main objective of the present invention is the synthesis of all the process related impurities present in Nafcillin Sodium, Active Pharmaceutical Ingredient (API).

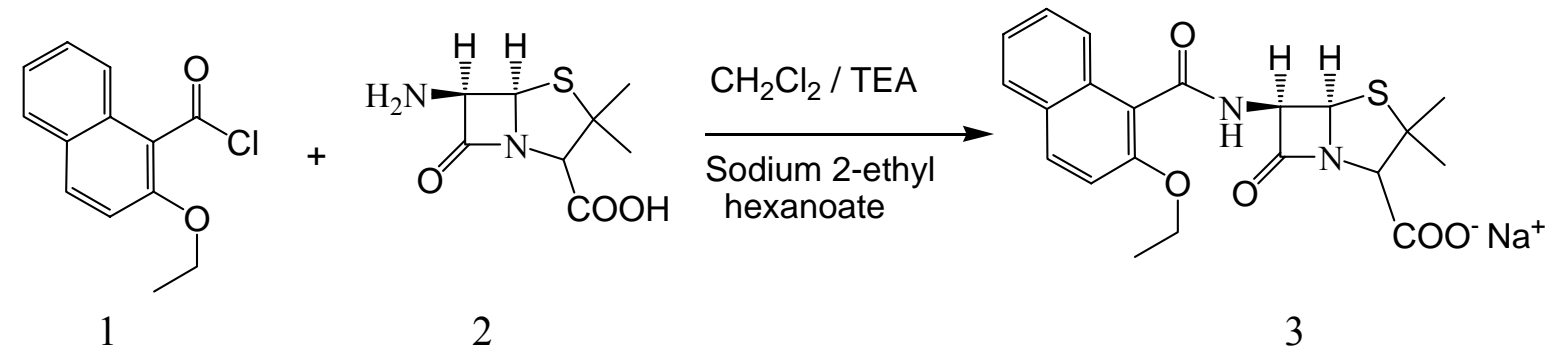

\section{Scheme 1}

It was found that Nafcillin sodium is very sensitive to water and it degrades to compound 4. This impurity has also increased during the stability studies. Therefore compound $\mathbf{4}$ has been identified as one of the potential impurities in Nafcillin Sodium. This impurity has been synthesized by hydrolyzing Nafcillin sodium at controlled $\mathrm{pH}$ by using inorganic base in $44 \%$ yield (Scheme 2). Similarly a more selective approach to compound 5 was performed by the decarboxylation of compound 4 with an acid in presence of mild reduced pressure (Scheme 2). 


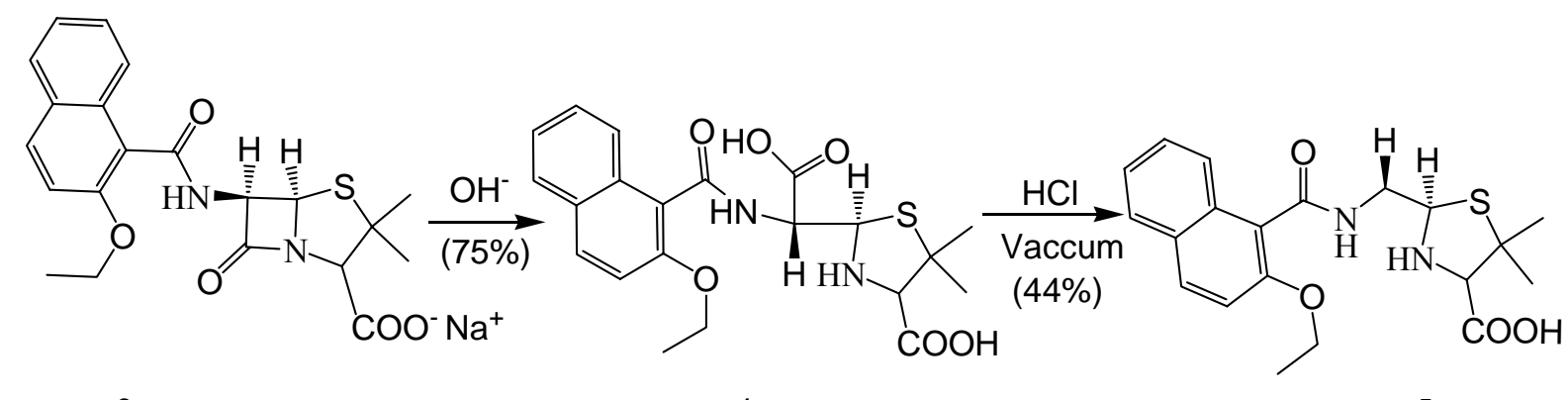

3

4

5

\section{Scheme 2}

Sulfoxides are very common impurities in penicillin antibacterial compounds. The elimination of these impurities from the final product is very difficult as they have similar solubility properties as Nafcillin sodium has. The aerial oxidation of sulphur causes the formation of Nafcillin sulfoxide during the synthesis of compound 3. It was synthesized by the treatment of Nafcillin sodium with per acetic acid in 30\% yield. (Scheme 3).

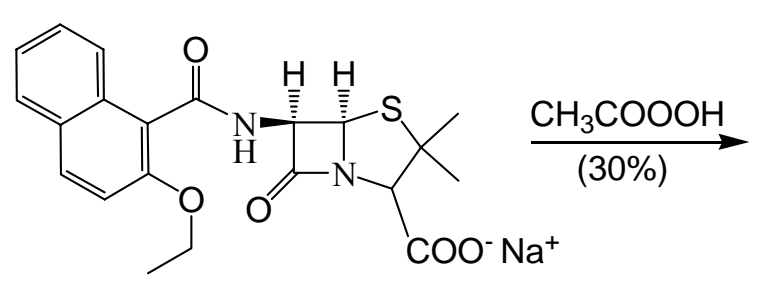

3

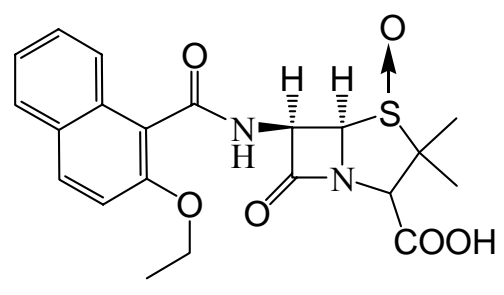

6

\section{Scheme 3}

Compound 8 is a structural isomer of Nafcillin sodium and is generated due to presence of 2methoxy-1-naphthoyl chloride 7 as an impurity in the key raw material 2-ethoxy-1-naphthoyl chloride 1. A more convenient method has been reported here for the preparation of compound 8 by the acylation of compound 3 with 7 in $60 \%$ yield (Scheme 4 ). In the reported methods ${ }^{8}$ the acylation reaction was carried out in chloroform and the sodium salt was isolated by the distillation of water under high vacuum. The main drawbacks of the reported methods are the use of chloroform, which is not recommended due to its hazardous properties. Similarly distillation of water is difficult and compound $\mathbf{8}$ is not stable in water. These draw backs led us to develop a new procedure for the synthesis of this compound. The reaction conditions are given in example 4 and the method is able to isolate compound $\mathbf{8}$ directly from the ethyl acetate solution with free of impurities. 
<smiles>COc1ccc2ccccc2c1C(=O)Cl</smiles>

7<smiles>CC1(C)S[C@H]2[C@H](N)C(=O)N2C1C(=O)O</smiles>

2

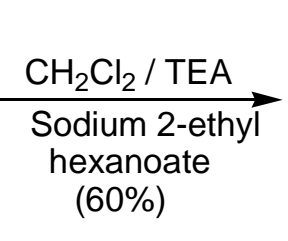

(60\%)

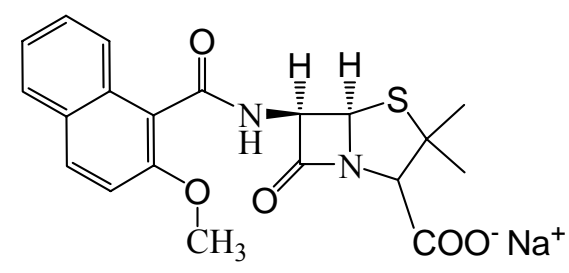

8

\section{Scheme 4}

Finally compound 9 is a methyl ester of hydrolyzed beta lactam ring, formed during the preparation of Nafcillin sodium. It results from the alcoholic hydrolysis of compound $\mathbf{3}$ during the isolation of Nafcillin Sodium. The work-up was carried out in a mixture of ethyl acetate and methanol. It was found that the isolation of Nafcillin Sodium is not possible in the absence of methanol. Therefore, it is necessary to use methanol for getting uniform crystals of Nafcillin sodium, which enhances the rate of filtration and affords Nafcillin sodium in high purity. Compound 9 was synthesized by the treatment of compound $\mathbf{3}$ with methanol in presence of base in $30 \%$ yield. (Scheme 5 ).

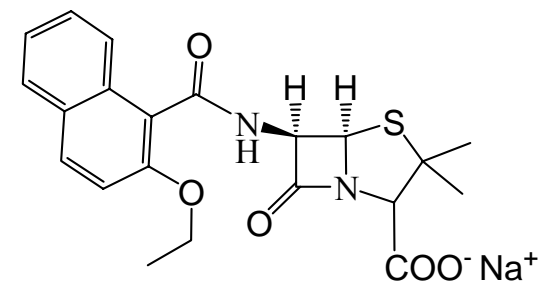

3

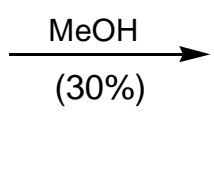

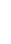

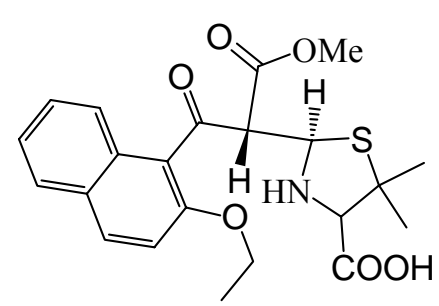

9

\section{Scheme 5}

\section{Experimental Section}

Synthesis of (2RS, 4S)-2-[I[(1r)-1-carboxy-1- (2-ethoxy-1-naphthyl) carbonyl]-amino] methyl]-5,5-dimethyl-1, 3-thiazolidine-4-carboxylic acid (4). To a precooled solution of compound $3(10 \mathrm{~g}, 0.023 \mathrm{~mol})$ in water $(50 \mathrm{ml})$ was adjusted $\mathrm{pH}$ between 12 and 12.5 with $10 \% \mathrm{w} / \mathrm{w}$ aqueous sodium hydroxide at $35-40^{\circ} \mathrm{C}$ and continued the stirring for $1 \mathrm{~h}$ at $35-40^{\circ} \mathrm{C}$ while maintain the $\mathrm{pH}$ between 12 and 12.5 . Thereafter, cooled the reaction mass to $5-10^{\circ} \mathrm{C}$ and $\mathrm{pH}$ adjusted to 3 with $20 \% \mathrm{w} / \mathrm{w}$ orthophosphoric acid. The precipitated product was filtered washed with water and dried to afford 4 as a pale yellow powder consists of a mixture of two stereo

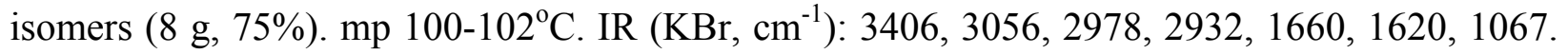
${ }^{1} \mathrm{H}-\mathrm{NMR}\left(300 \mathrm{MHz}, \mathrm{D}_{2} \mathrm{O}\right): \delta 1.29(\mathrm{t}, 3 \mathrm{H}) ; 1.35$ and $1.41(2 \mathrm{~s}, 3 \mathrm{H}) ; 1.57$ and $1.60(2 \mathrm{~s}, 3 \mathrm{H}) ; 4.04$ and $4.09(2 \mathrm{~s}, 1 \mathrm{H}) ; 4.19(\mathrm{q}, 2 \mathrm{H}) ; 4.92$ and $4.96(2 \mathrm{~d}, 1 \mathrm{H}) ; 5.35$ and $5.55(2 \mathrm{~d}, 1 \mathrm{H}) ; 7.34-7.94(\mathrm{~m}$, 
$6 \mathrm{H}) \mathrm{ppm} .{ }^{13} \mathrm{C}-\mathrm{NMR}\left(300 \mathrm{MHz}, \mathrm{D}_{2} \mathrm{O}\right): \delta 15.6,15.7,27.8,28.8,29.1,29.9,56.5,58.5,58.9,65.5$, 65.9, 68, 71.1, 74.8, 76.2, 115.9, 116.2, 116.4, 122.3, 123, 124.6, 125.7, 126, 127.4, 127.6, 127.7, 128.4, 129, 130.8, 131.2, 131.8, 153.1, 167, 167.6, 171.7, 172, 172.5. MS (ESI $\left.{ }^{+}\right): \mathrm{m} / \mathrm{z} 431.1$ (MH). Anal. Calcd. For $\mathrm{C}_{21} \mathrm{H}_{24} \mathrm{~N}_{2} \mathrm{O}_{6} \mathrm{~S}$ : C, 58.32; H, 5.59; N, 6.48; S, 7.41. Found: C, 58.55; H, 5.62, N, 6.50, S, $7.43 \%$.

Synthesis of (2RS, 4S)-2-[I[(2-ethoxy-1-naphthyl) carbonyl] amino] methyl]-5, 5-dimethyl-1, 3-thiazolidine-4-carboxylic acid (5). Compound 4 (5 g, $0.0116 \mathrm{~mol}$ ) was suspended in a mixture of water $(50 \mathrm{ml})$ and acetone $(30 \mathrm{ml})$ at $25-30^{\circ} \mathrm{C} . \mathrm{pH}$ was adjusted to $0.1-0.2$ with hydrochloric acid and heated to $70^{\circ} \mathrm{C}$ under reduced pressure $(400 \mathrm{mmhg})$ for $1 \mathrm{~h}$. Thereafter the reaction mass was cooled to room temperature and poured in to $5 \% \mathrm{w} / \mathrm{w}$ sodium bicarbonate solution $(50 \mathrm{ml})$ and filtered the undissolved material. The filtrate was cooled to $5^{\circ} \mathrm{C}$ and $\mathrm{pH}$ adjusted to 3 with aqueous ammonia. The precipitated solid was filtered, washed with water and dried to afford compound 5 as a pale yellow powder consists of a mixture of two stereo isomers $(2 \mathrm{~g}, 44 \%)$. mp 95-96 C. IR (KBr, cm $\left.{ }^{-1}\right): 3412,3380,2975,2930,1727,1638,1595,1515$, 1464, 1247. ${ }^{1} \mathrm{H}-\mathrm{NMR}\left(300 \mathrm{MHz}, \mathrm{DMSO}-\mathrm{d}_{6}\right): \delta 1.20$ and $1.58(2 \mathrm{~s}, 6 \mathrm{H}) ; 1.33(\mathrm{t}, 3 \mathrm{H}) ; 3.33(\mathrm{~m}$, $2 \mathrm{H}) ; 3.35$ and $3.50(2 \mathrm{~s}, 1 \mathrm{H}) ;, 4.19(\mathrm{q}, 2 \mathrm{H}) ; 4.80$ and $4.90(2 \mathrm{t}, 1 \mathrm{H}) ; 7.36-7.94(\mathrm{~m}, 6 \mathrm{H}) ; 8.39$ and $8.55(2 \mathrm{t}, 1 \mathrm{H}) .{ }^{13} \mathrm{C}-\mathrm{NMR}\left(300 \mathrm{MHz}, \mathrm{DMSO}_{-} \mathrm{d}_{6}\right): \delta 15.7,15.8,28.3,28.9,29.3,29.9,43.4,47.2$, 59.6, 60.1, 65.6, 66.4, 68, 73.5, 76.1, 16.1, 123.1, 124.5, 124.6, 125.3, 125.5, 127.5, 128.5, 129 ,

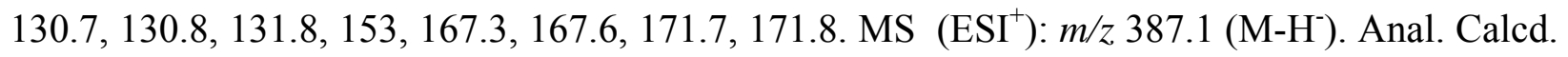
For $\mathrm{C}_{20} \mathrm{H}_{24} \mathrm{~N}_{2} \mathrm{O}_{4} \mathrm{~S}$ : C, 61.83; H, 6.23; N, 7.21; S, 8.25. Found: C, 61.90; H, 6.25, N, 7.23, S, $8.28 \%$.

Synthesis of (2S, 5R, 6R)-6-(2-ethoxy-1-naphthyl) carbonyl]-amino] 3, 3-dimethyl-7-oxo-4thia-1-azabicyclo [3.2.0] heptane -2- carboxylic acid-4-oxide (6). 27\% w/w, per acetic acid $(6.8 \mathrm{~g}$,) was added to a precooled solution of Compound $3(10 \mathrm{~g}, 0.023 \mathrm{~mol})$ in acetone $(100 \mathrm{ml})$ at $0^{\circ} \mathrm{C}$ in $30 \mathrm{~min}$. Thereafter, the reaction mixture was stirred at the same temperature for $1 \mathrm{~h}$. Acetone was distilled off and the residue was dissolved in ethyl acetate $(100 \mathrm{ml})$ and washed with water $(100 \mathrm{ml})$. Organic layer was concentrated to $25 \mathrm{ml}$ volume and allowed to settle for $15 \mathrm{~h}$. The crystals obtained were filtered washed with pre-cooled ethyl acetate $(5 \mathrm{ml})$ and dried under reduced pressure to afford 6 as white crystalline powder $(3.5 \mathrm{~g}, 30 \%) \mathrm{mp} 148-156^{\circ} \mathrm{C}$ (decomp). IR (KBr, cm ${ }^{-1}$ ): 3401, 3371, 2971, 2930, 2892, 1784, 1736, 1645, 1596, 1500, 1463, 1069. ${ }^{1} \mathrm{H}-\mathrm{NMR}\left(300 \mathrm{MHz}, \mathrm{DMSO}-\mathrm{d}_{6}\right): \delta 1.26$ and $1.58(2 \mathrm{~s}, 6 \mathrm{H}), 1.38(\mathrm{t}, 3 \mathrm{H}), 4.23(\mathrm{q}, 2 \mathrm{H}), 4.39$ $(\mathrm{s}, 1 \mathrm{H}), 5.66(\mathrm{~d}, 1 \mathrm{H}), 6.24(\mathrm{dd}, 1 \mathrm{H}), 7.38-7.91(\mathrm{~m}, 6 \mathrm{H}), 8.02(\mathrm{~d}, 1 \mathrm{H}), 13.5$ (brs, $1 \mathrm{H}) .{ }^{13} \mathrm{C}-\mathrm{NMR}$ (300 MHz, DMSO-d $): \delta 15.6,18.8,19.8,56.5,65.6,66.6,66.7,75.4,76.8,115.5,119.6,124.6$,

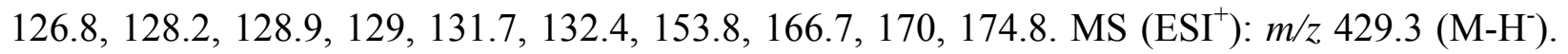
Anal. Calcd. For $\mathrm{C}_{21} \mathrm{H}_{22} \mathrm{~N}_{2} \mathrm{O}_{6} \mathrm{~S}: \mathrm{C}, 58.59 ; \mathrm{H}, 5.15 ; \mathrm{N}, 6.51 ; \mathrm{S}, 7.45$. Found: C, 58.60; H, 5.15, $\mathrm{N}, 6.52, \mathrm{~S}, 7.44 \%$.

Synthesis of sodium (2S, 5R, 6R)-6-(2-methoxy-1-naphthyl) carbonyl]-amino] 3, 3-dimethyl7-oxo-4-thia-1-azabicyclo [3.2.0] heptane -2- carboxylate. (8). Add triethylamne (10.g, 0.099 $\mathrm{mol})$ to a precooled suspension of compound $2(10 \mathrm{~g}, 0.046)$ in methylene chloride $(100 \mathrm{ml})$ at 0 $5^{\circ} \mathrm{C}$ and stirred for $30 \mathrm{~min}$ at the same temperature. Acid chloride 7 (10.20 g, $0.046 \mathrm{~mol}$ ) was 
added in $15 \mathrm{~min}$ at $0-5^{\circ} \mathrm{C}$ and continued the stirring for another $15 \mathrm{~min}$ at the same temperature. Water $(25 \mathrm{ml})$ was added and lowers the $\mathrm{pH}$ to $3-3.5$ with aqueous phosphoric acid $(2.70 \mathrm{ml})$. Aqueous layer was separated and extracted with methylene chloride $(25 \mathrm{ml})$. The combined organic extract was washed with water $(50 \mathrm{ml}) .5 \% \mathrm{w} / \mathrm{w}$ aqueous sodium bicarbonate $(130 \mathrm{ml})$ was added to the organic layer. The aqueous layer was separated and diluted with ethyl acetate $(200 \mathrm{ml})$ and adjusted the $\mathrm{pH}$ to $3-3.5$ with phosphoric acid $(7.3 \mathrm{ml})$ at $10-15^{\circ} \mathrm{C}$. The ethyl acetate layer was separated and dried over sodium sulfate to attain the water content less than $2 \%$ $\mathrm{w} / \mathrm{w}$. Methanol $(10 \mathrm{ml})$ was added to the ethyl acetate solution followed by ethyl acetate solution of sodium 2-ethylhexanoate $(7.4 \mathrm{~g}, 0.0445 \mathrm{~mol})$ in $45 \mathrm{~min}$ at $20-30^{\circ} \mathrm{C}$. Thereafter continued the stirring for $30 \mathrm{~min}$ to complete the precipitation. The solid was filtered and washed with ethyl acetate $(50 \mathrm{ml})$ and dried to yield 8 as white crystalline powder $(11.1 \mathrm{~g}, 60 \%) \mathrm{mp} 148-156^{\circ} \mathrm{C}$ (decomp). IR (KBr, cm ${ }^{-1}$ ): 3365, 3260, 2987, 2942, 2838, 1765, 1658, 1606, 1513, 1410, 1076. ${ }^{1} \mathrm{H}-\mathrm{NMR}\left(300 \mathrm{MHz}, \mathrm{DMSO}-\mathrm{d}_{6}\right): \delta 1.43 \& 1.47(2 \mathrm{~s}, 6 \mathrm{H}) ; 3.78(\mathrm{~s}, 3 \mathrm{H}) ; 4.13(\mathrm{~s}, 1 \mathrm{H}) ; 5.57 \& 5.65$ (2d, 2H); 7.18-7.79 (m, 6H). ${ }^{13} \mathrm{C}-\mathrm{NMR}\left(300 \mathrm{MHz}, \mathrm{DMSO}-\mathrm{d}_{6}\right): \delta 26.91,30.60,56.74,58.30$, 65.01, 66.95, 73.65, 113.37, 117.20, 123.83, 124.35, 127.95, 128.38, 129, 131.10, 132.25, 154.40, 168.50, 174, 174.80. MS (ESI $\left.{ }^{+}\right): m / z$ 399.1 (M-H'). Anal. Calcd. For $\mathrm{C}_{20} \mathrm{H}_{19} \mathrm{~N}_{2} \mathrm{Na} \mathrm{O}_{5} \mathrm{~S}$ : C, 56.87; H, 4.50; N, 6.64; S, 7.58. Found: C, 56.90; H, 4.50, N, 6.62, S, $7.54 \%$.

Synthesis of (2RS, 4S)-2[I[(1R)-(methoxycarbonyl)-1-(2-ethoxy-1-naphthyl) carbonyl]-amino]-5, 5dimethyl-1,3-thiazolidine-4-carboxylicacid (9). Sodium 2-ethylhexanoate (3.8 g, 0.023 $\mathrm{mol})$ was added to a solution of Compound $3(10 \mathrm{~g}, 0.023 \mathrm{~mol})$ in methanol $(100 \mathrm{ml})$ at $25-30^{\circ} \mathrm{C}$. Thereafter, the reaction mixture was heated to $40-45^{\circ} \mathrm{C}$ for $15 \mathrm{~h}$. Methanol was distilled under reduced pressure to obtain the crude product. A portion of crude product ( $2 \mathrm{~g})$ was purified by using preparative liquid chromatography to yield $\mathbf{9}$ as a white amorphous powder $(0.6 \mathrm{~g}, 30 \%)$. mp 65-66 ${ }^{\circ} \mathrm{C} .{ }^{1} \mathrm{H}-\mathrm{NMR}\left(300 \mathrm{MHz}, \mathrm{DMSO}-\mathrm{d}_{6}\right): \delta 1.20$ and $1.55(2 \mathrm{~s}, 6 \mathrm{H}) ; 1.32(\mathrm{t}, 3 \mathrm{H}) ; 3.56(\mathrm{~s}$, $1 \mathrm{H}) ; 3.69(\mathrm{~s}, 3 \mathrm{H}) ; 4.17(\mathrm{q}, 2 \mathrm{H}) ; 4.71(\mathrm{~m}, 1 \mathrm{H}) ; 4.95(\mathrm{~d}, 1 \mathrm{H}) ; 7.33-7.55(\mathrm{~m}, 6 \mathrm{H}) ; 8.72(\mathrm{~d}, 1 \mathrm{H}) .{ }^{13} \mathrm{C}-$ NMR (300 MHz, DMSO-d d $_{6}$ ): $\delta 15.7,28,28.4,52.7,58.4,59.9,65.8,66.8,73.8,116.4,122.6$, 124.6, 125.9, 127.4, 128.4, 129.0, 130.9, 131.9, 153.2, 167.4, 171.4. IR (KBr) cm$)^{-1}: 3405,1738$, 1650, 1595, 1514, 1465, 1025. MS (ESI $\left.{ }^{+}\right): m / z$ 445.2 (M-H'). Anal. Calcd. For $\mathrm{C}_{22} \mathrm{H}_{25} \mathrm{~N} \mathrm{O}_{6} \mathrm{~S}$ : C, 61.24; H, 5.84; N, 3.25; S, 7.43. Found: C, 61.45; H, 5.85, N, 3.24, S, $7.44 \%$.

\section{Acknowledgements}

The authors wish to thank the management of Aurobindo Pharma Research Centre for supporting this work. Cooperation from collegues of Chemical Research and Analytical Research departments is appreciated 


\section{References and Notes}

1. Doyle, F. T.; Charles, J. H.; Rolinson, G, GB Patent 1962, 880440; Chem. Abstr. 1962, 57, 13763b.

2. Vikrova, N. M.; Strukov, I. T.; Tebyakina, A. E.; Chaikovchaya, S. M.; Shneerson, A. N.; Dubora, V. G, Antibiotiki. 1965, 19, 3.

3. Doyle, F. P.; Herbert, J.; Nayler, C. US Patent 1964, 3,157,639; Chem. Abstr. 1965, 62, 9140e.

4. Flitter, D.; Nescio, J. J.; Mongelluzzo, S. P, US Patent 1970, 3,506,645; Chem. Abstr. 1973, 78, 25455x.

5. Childress, S. J, US Patent 1966, 3,248,386; Chem.Abstr. 1966, 64, 19624 b.

6. Ashline, K. A.; Atrill, R. P.; Chess, E. K.; Clayton, J. P.; Cutrole, E. A.; Eeverelt, J. R.; Nayler, J.H .C.; Pereira, D. E.; Smith, W.J.; Tyler, J.W.; Vieria, M. L. J. Chem. Soc. Perkin Trans. 1990; 2,1559.

7. ICH Guideline Q3A (R), Impurities in New Drug Substances. 2002, 7 February.

8. Brain, E. G.; Doyle, F. P.; Mehta, M. D.; Miller, D.; Nayler, J. H. C.; Stove, E. V, J. Chem. Soc. 1963, 491. 